Discussion Paper No. 10-032

\title{
Churning of R\&D Personnel and Innovation
}

Kathrin Müller and Bettina Peters

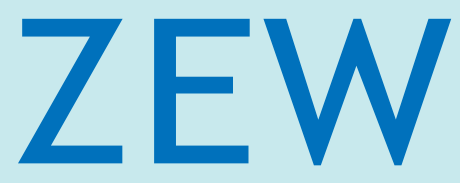

Zentrum für Europäische Wirtschaftsforschung $\mathrm{GmbH}$

Centre for European

Economic Research 
Discussion Paper No. 10-032

\title{
Churning of R\&D Personnel and Innovation
}

\author{
Kathrin Müller and Bettina Peters
}

Download this ZEW Discussion Paper from our ftp server:

ftp://ftp.zew.de/pub/zew-docs/dp/dp10032.pdf

Die Discussion Papers dienen einer möglichst schnellen Verbreitung von neueren Forschungsarbeiten des ZEW. Die Beiträge liegen in alleiniger Verantwortung der Autoren und stellen nicht notwendigerweise die Meinung des ZEW dar.

Discussion Papers are intended to make results of ZEW research promptly available to other economists in order to encourage discussion and suggestions for revisions. The authors are solely responsible for the contents which do not necessarily represent the opinion of the ZEW. 


\section{Non-technical Summary}

This paper investigates the effect of mobility among a firm's R\&D personnel on its innovation performance.

Since knowledge created within an R\&D department of a firm is largely embodied in the person of the individual researcher, firms might gain access to external knowledge via hiring new staff. Consequently, innovation should be enhanced. However, firms may suffer from a simultaneous outflow of R\&D workers.

Our empirical analysis falls back on theories developed by Jovanovic (1979) and Cooper (2001). According to these theories, labor mobility increases the employer-employee matching quality within the R\&D department (Jovanovic, 1979). Moreover, as long as the R\&D knowledge of a leaving worker can be still used by the worker's former employer, overall labor mobility results in net inflows of R\&D knowledge and thus should stimulate innovation (Cooper, 2001).

To disentangle the effects of net gains or losses in R\&D personnel and replacements within the R\&D department is the major aim of this study. We employ, besides net growth in R\&D personnel, churning as a measure for R\&D worker mobility. Churning depicts the number of workers which are replaced by new ones, i.e. it is an employment-neutral measure of labor turnover. Furthermore, we distinguish between different types of innovations, namely between process and product innovations as well as between market and product-range novelties.

Using two sets of bivariate probit regressions, we estimate various knowledge production functions. Labor mobility is found to enhance innovation performance up to a certain threshold. Interestingly, this threshold differs between the types of innovation. The optimal amount of churning among R\&D works is lower for process innovations than for product innovations. This result is intuitive since process innovation will require much more firm-specific knowledge and less external knowledge. Our regressions further indicate that a positive effect of labor mobility on innovation performance depends crucially on the appropriability regime. If $\mathrm{R} \& \mathrm{D}$ knowledge is characterized by rivalry in its application, i.e. it is non-duplicative, the threshold up to which a positive effect of labor mobility can be observed is considerably lower. 


\section{Das Wichtigste in Kürze}

Die vorliegende Studie untersucht den Zusammenhang zwischen der Mobilität von Mitarbeitern im Bereich von Forschung und Entwicklung (FuE) und dem Innovationserfolg deutscher Unternehmen.

Durch die Einstellung neuer FuE-Mitarbeiter können Firmen neues externes Wissen akquirieren und damit ihre Chancen auf die erfolgreiche Einführung neuer Produkte und Produktionsprozesse erhöhen. Umgekehrt besteht die Gefahr, dass im Unternehmen vorhandenes Wissen verloren geht, wenn FuE-Mitarbeiter ausscheiden. Sofern die Unternehmen die Forschungsergebnisse ihrer Mitarbeiter jedoch auch nach deren Ausscheiden noch anwenden können, sollte die Fluktuation unter FuE-Beschäftigten insgesamt zu einem Zufluss an Wissen führen und damit Innovationen stimulieren, wie das theoretisches Modell von Cooper (2001) zeigt. Darüber hinaus ist auf Basis von Matching-Theorien (Jovanovic, 1979) zu erwarten, dass ein gewisses Maß an Fluktuation dafür sorgt, dass Mitarbeiter-Matches von schlechter Qualität aufgelöst und neue, bessere Matches eingegangen werden.

Um im Rahmen unserer Analysen den Effekt eines Nettozuwachses oder Nettoverlusts von FuE-Mitarbeitern von dem Effekt einer Auswechslung von FuEMitarbeitern auf die Innovationstätigkeit von Unternehmen zu trennen, greifen wir auf ein Maß zurück, das bisher nur in arbeitsmarktökonomischen Studien verwendet wurde, das Churning von Mitarbeitern. Dieses Maß bildet die Anzahl von Mitarbeitern ab, die durch andere, neue Mitarbeiter ersetzt wurden, d.h. dieses Maß ist beschäftigungsneutral. Weiterhin unterscheiden wir zwischen verschiedenen Innovationsarten. Wir trennen zum einen zwischen Produkt- und Prozessinnovationen und zum anderen zwischen Markt- und Sortimentsneuheiten.

Mit Hilfe bivariater Probitmodelle schätzen wir vier Wissensproduktionsfunktionen und können zeigen, dass für alle vier Innovationsarten ein umgekehrt uförmiger Verlauf zwischen der Mobilität von FuE-Mitarbeitern und dem Innovationserfolg besteht. Dies bedeutet, dass die Fluktuation das Innovationsergebnis bis zu einem gewissen Schwellenwert steigert. Dieser Schwellwert variiert je nach Art der Innovation. So dreht sich der Effekt im Falle von Prozessinnovationen wesentlich früher ins Negative (bei einer Churningrate von 30 v.H.) als im Fal- 
le von Produktinnovationen (65 v.H.). Daraus lässt sich schlussfolgern, dass die Entwicklung neuer Prozesse mehr firmenspezifisches Wissen erfordert als die Entwicklung neuer Produkte. Unsere Ergebnisse zeigen ferner, dass die Mobilität von FuE-Beschäftigten insbesondere die Wahrscheinlichkeit für Produktinnovationen erhöht, die eine Erweiterung ihres bisherigen Produktsortiments darstellen. Die mit der Mobilität von FuE-Mitarbeitern einhergehenden positiven Innovationswirkungen sind darüber hinaus abhängig von der Art des im Zuge der FuETätigkeit geschaffenen Wissens. Besteht Rivalität in der Nutzung des Wissens verringern sich die positiven Effekte durch die Fluktuation. 


\title{
Churning of R\&D Personnel and Innovation
}

\author{
Kathrin Müller ${ }^{a, *}$ \\ Bettina Peters ${ }^{a, b}$ \\ ${ }^{a}$ Centre for European Economic Research (ZEW) \\ ${ }^{b}$ University of Zurich
}

This version: May, 2010

\begin{abstract}
This paper explores the role of $\mathrm{R} \& \mathrm{D}$ worker mobility on innovation performance. As one main novelty, we employ churning as a measure for worker mobility. Churning depicts the number of workers which are replaced by new ones. It is a very informative indicator since a firm may be exposed to simultaneous leave and inflow of $R \& D$ workers even if the size of R\&D employment remains unchanged. Hence, we can separate the effect of replacement from net change in R\&D workforce. Our results from estimating various knowledge production functions suggest an inverse u-shaped relationship. The exchange of R\&D personnel fosters innovation through inter-firm knowledge spillovers and improved job-match quality up to certain threshold. The point when costs of churning exceed the benefits is reached faster if the R\&D knowledge is non-duplicative.
\end{abstract}

Keywords: innovation, churning, mobility

JEL Classification: 032, O33, C35

\footnotetext{
${ }^{*}$ Corresponding author: P.O. Box 103443, 68034 Mannheim, Germany. Phone: +49 621 1235-385, Fax: +49621 1235-170. E-mail: kathrin.mueller@zew.de Acknowledgments: We are grateful to Christian Rammer and participants at seminars at the ZEW and KU Leuven for valuable comments and discussions.
} 


\section{Introduction}

Indisputably, knowledge has been identified as the key input for developing innovations. Because of the rapidly increasing speed of technological changes and increasing technological complexity of products and processes, firms have to source outside knowledge in order to complement internal knowledge. A body of literature has thus focussed on firms' strategies of how to gain access to new knowledge and on the effectiveness of these strategies in terms of innovation performance. Main routes of how firms can tap new external knowledge are cooperations and strategic alliances with other actors (competitors, science, customers, clients), licensing of technology, mergers and acquisitions, contract R\&D, and the hiring of new labor (see Teece, 1986, 1992; Hagedoorn, 2002; Cassiman and Veugelers, 2006). ${ }^{1}$

Several strands of the literature emphasize a stimulating effect of recruiting new personnel on knowledge creation and innovation (Rao and Drazin, 2002). The main argument relies on the fact that knowledge originating from R\&D and competencies are largely embodied in people. According to the resource-based view of the firm, hiring new personnel is thus seen as an important mechanism for acquiring skills (Barney, 1991). In addition, it is an important way of exchanging ideas, learning from competitors, and imitating their innovations (institutional perspective). The network theory furthermore stresses that hiring new personnel facilitates the establishment of new connections and a professional community (Baker, 1994).

However, it is often neglected in this literature that hiring a new worker may be associated with the departure of previous workers. That is, we can often simultaneously observe hirings and separations of workers within a firm. In labor economics, determinants of simultaneous hiring and firing and its influence on firm performance have been investigated (see Burgess et al., 2000a; Ilmakunnas et al., 2005). For R\&D personnel, one can likewise observe simultaneous inflow

\footnotetext{
${ }^{1}$ Studies which support the complementarity between internal and external knowledge include among others Arora and Gambardella (1994) and Cassiman and Veugelers (2006). Cassiman and Veugelers (2007) provide evidence that different external technology sourcing strategies are complements in large and substitutes in small firms.
} 
and outflow of workers. The mobility of workers among firms presents a way of knowledge diffusion and is thus a major source of potential spillovers. As a consequence, a firm may benefit from incoming spillovers and suffer from knowledge outflows (outgoing spillovers) at the same time. Besides getting access to new knowledge, labor reallocation may also be driven by improving the match between the skills firms demand and employees provide (Jovanovic, 1979). If firms successfully bring qualification demand into line with supply, this should pay off in a better performance.

In this paper, we address the question of how the reallocation of $R \& D$ workers affects future innovation activities of firms. Empirical evidence on the dynamics of worker flows of R\&D personnel and its influence on a firm's innovation performance is scarce. Prior studies look a the effect of new R\&D workers or net R\&D employment gains. We contribute to the literature in three ways: First, we employ churning of R\&D personnel as an indicator for R\&D worker flows. Churning is a well-established concept in labor economics. The main advantage is that it abstracts from net employment gains or losses and only measures the number of workers replaced by new ones, i.e. it depicts an employment-neutral measure of labor turnover. This feature allows us to separately identify the effect of replacement and net change in the R\&D workforce on innovation in the empirical analysis. As a second novel aspect, we investigate whether the effect of labor mobility differs according to the type of innovation. That is, we distinguish between product and process innovation in a first step and then furthermore discriminate between different types of product innovations (market novelties, product-range novelties). We suppose that churning is more beneficial for innovations with a higher degree of novelty for the firm, i.e. if more external knowledge is required. Finally, we test the hypothesis that the role of churning on innovation depends on whether the knowledge which is transferred through mobility can be used by both the donor and the recipient firm simultaneously afterwards.

The answer to the question of how innovation is influenced by worker mobility is naturally interesting from a management perspective. If churning lowers innovation performance in the future, firms should for instance consider implementing stronger mechanism to protect their knowledge and setting better incentive 
schemes for R\&D workers to stay within the firm. It is likewise interesting from a policy point of view. If churning exerts a positive impact on innovation through better job-match qualities and the diffusion of knowledge, loosening up strong dismissal protection may be a route to foster innovation.

To answer our research question, we estimate two knowledge production functions using bivariate probit models (Pakes and Griliches, 1984). The empirical analysis is based on a sample of about 1,500 German firms collected within the Community Innovation Surveys (CIS). In contrast to Kaiser et al. (2008) who find a positive net effect of labor mobility - as measured by the sum of the contributions of R\&D workers joining and leaving the firm, respectively - on patenting activity, our results point toward a non-linear inverse u-shaped relationship. Churning of R\&D personnel increases the probability of successfully implementing innovations up to a specific point. If, however, the exchange of $R \& D$ workers exceeds this threshold, the effect of churning becomes negative. This implies that the firm cannot compensate the erosion of the existing knowledge base by the inflow of new knowledge. We furthermore provide evidence that the impact of churning differs according to the type of innovation.

The outline of the paper is as follows. Section 2 sketches the main theoretical arguments of how churning may affect innovation performance at the firm level. Furthermore, it summarizes the scarce empirical evidence on the effect of labor mobility on innovation. Section 3 presents our empirical analysis: The data set is explored in subsection 3.1, followed by the description of the variables and estimation strategy in subsection 3.2. Subsection 3.3 sets forth the econometric results. Section 4 summarizes our main findings and discusses management implications.

\section{Mobility of $R \& D$ personnel and innovative output}

A firm's R\&D knowledge is primarily embodied in persons which implies that firms are not fully able to exercise property rights over their R\&D knowledge. Therefore, R\&D workers can potentially profit from their knowledge through job 
mobility. In this respect, traditional reasoning assumes that high worker flows result in lower appropriability of workers' knowledge, less incentives to innovate, and an under-investment in R\&D and training. Kim and Marschke (2005) develop a model in which the risk that a rival firm imitates a firm's new products after a scientist's departure can be mitigated by patenting. They show theoretically and empirically that the risk of a scientist's departure both reduces $R \& D$ expenditures and raises the probability of patenting.

However, the presence of large job-flows within highly innovative clusters (Fallick et al., 2006) has encouraged researchers to study the effect of labor mobility on cluster development. These studies have shown the importance of labor mobility for the success of clusters like Silicon Valley and other high-tech clusters (Saxenian, 1994; Almeida and Kogut, 1999; Fallick et al., 2006).

Driven by this "job hopping" phenomenon observed in technology clusters, Cooper (2001) developed a theoretical model of job mobility which serves as a vehicle for intra-industry knowledge diffusion. Unlike traditional reasoning, his model predicts that a higher mobility does not necessarily reduce firms' $R \& D$ investments and always coincides with greater overall technological progress of a firm. The reasoning behind that is that knowledge dissemination is facilitated by worker mobility. Cooper's model assumes that a firm retains a benefit of a worker's knowledge and information generated during the employment spell at the respective firm even after the employee has left to a competitor. The model stresses the duplicative nature of R\&D knowledge. That means, R\&D knowledge is partly non-rivalrous and can by utilized by more than one firm simultaneously. Therefore, a firm invests in training and $R \& D$ even when it has to expect intense movements of employees.

From this reasoning, one can expect that inter-firm mobility of $R \& D$ personnel increases the innovative abilities of firms by increasing the stock of appropriable knowledge which can be claimed to be a fundamental innovation input. Since many econometric studies have shown that innovation input significantly determines innovation output (see e.g. Crépon et al., 1998; Love and Roper, 2001), we expect inter-firm mobility of $R \& D$ personnel to result in higher innovative performance. 
Another line of reasoning why the mobility of $R \& D$ personnel is linked to innovative output stems from the fact that both worker and employer are faced with incomplete information in job matching. Before a person is hired the firm has incomplete information on a workers abilities and skills. Additionally, the worker has limited information about the tasks he is expected to perform. However, the tasks a certain job requires should match a workers abilities and skills in order to maximize the worker's productivity. The optimal allocation of workers to jobs is thus a central problem. Assigning the right worker to a specific job is crucial for both the firm, which aims to maximize profits, and the employee, who wants to maximize earnings.

The importance of job match quality is highlighted in theoretical (Jovanovic, 1979) and empirical models (Liu, 1986; Topel and Ward, 1992) of job matching and labor turnover. In these models, a job match is assumed to be an experience good (Jovanovic, 1979), i.e. the quality of a job match can only be determined by "experiencing" it after the job match has been formed. The firm can only learn about the quality of the job match by observing the worker on the job for a period of time (Topel and Ward, 1992). After new information is obtained about the worker's productivity on a specific job, a reassignment of employer-employee matches may become optimal. While matches of sufficiently high quality are sustained, a job match is dissolved if the worker's job specific productivity is revealed to be relatively low, i.e. if the job match is of poor quality. Thus, labor turnover is the result of searching for matches of higher quality when better information about the match quality is accumulated over time. Accordingly, labor mobility may improve the match quality between the firm and the employee. As a result, labor productivity is enhanced. This reasoning is in line with the results of Pakes and Nitzan (1983) who develop a model of optimum labor contracts for research personnel. They find that labor mobility does not harm an R\&D projects profitability as long as firms can freely choose among alternative labor contracts. In this case, a firm can set up an incentive scheme which induces a scientist only to leave if it is in the firm's interest for the scientist to do so.

A good match is of particular importance when searching for highly-productive $R \& D$ workers. The ideas, abilities, and skills of R\&D workers have to fit both 
into the business activities of a firm and into the research team they are assigned to.

The equilibrium result of workers' self-selection out of poor quality matches in the theoretical model of Jovanovic (1979) requires either a sufficient wage flexibility or a limited amount of dismissal protection regulations. However, the labor market in Germany is characterized by strong unions and intense dismissal protection. One can thus expect that it is either not possible or rather costly to dissolve a match of poor quality. Furthermore, firms may be faced with an intense shortage of labor supply of highly qualified and highly specialized researchers.

One possibility of describing and measuring labor mobility within a firm is the concept of churning. Churning, also called excess labor reallocation, arises when a firm simultaneously experiences separations and hires. It measures the amount of workers which are successfully replaced by other workers. ${ }^{2}$ This measure was developed and introduced by labor economists who wanted to describe and explain employment dynamics within sectors and within firms (Lane et al., 1996; Burgess et al., 2000a,b, 2001). Churning is an employment-neutral measure of labor turnover, i.e. the measure abstracts from net employment gains or losses and only measures the number of replaced workers. A low amount of churning might characterize firms which are either not able to dissolve job matches of poor quality or which are able to dissolve poor matches but do not succeed in forming new matches. According to this line of reasoning a low amount of churning means to suffer from retaining poor matches. Therefore, a positive effect of churning on innovation output can be supposed.

On the other hand, if the amount of churning is very high, e.g. if a firm replaces almost all its R\&D workers, the firm's knowledge stock will be eroded. What is more, hiring new workers can cause sizeable transaction costs. The firm has to look for new R\&D workers and sometimes the firm might not manage to hire new workers reasonably soon. Furthermore, new workers need to be instructed. Instruction and training of new workers raises costs, especially when a large amount of time of the experienced $R \& D$ workers is needed to train new R\&D personnel properly. Therefore, the effects of churning on innovation are

\footnotetext{
${ }^{2}$ The churning measure is explained in detail in section 3.2
} 
expected to be negative if the amount of churning exceeds a certain threshold. All together, the relationship between churning and innovation is expected to be inverse u-shaped (which was also assumed by Ettlie, 1985).

The importance of labor mobility for technological performance is highlighted by the results of a couple of empirical studies. These studies can be classified into three groups according to their level of analysis. In addition to the cluster or regional level (see Saxenian, 1994), researchers examined this question at the level of the firm and the individual worker, respectively.

At the individual level, empirical evidence is mixed. Hoisl (2007) tracks mobile inventors using official data from patent files. She finds mobile inventors to be more productive in terms of patent applications than non-movers. In contrast to the findings of Hoisl (2007) for German inventors, Aoshima (2008) does not find a positive effect on the innovative behavior of semiconductor engineers in Japan. He even finds a negative effect of the number of inter-organizational and intraorganizational transfers on an engineer's technological performance as measured by the number of patents and the number of published papers.

Rao and Drazin (2002) tested several hypothesis concerning the recruitment of new personnel and product innovation using a sample of mutual fund families. They expected that the recruitment of talents from rivals helps to overcome resource constraints on product innovation, e.g. poor connectedness in case of the mutual funds industry. Analyzing the recruiting and innovation behavior of these funds, they find that the number of stock portfolio manager recruits has a positive influence on the probability of introducing a product innovation. Furthermore, recruits' characteristics are found to increase product innovations.

Ettlie (1985) conducted correlation analyses in order to test several hypotheses concerning net manpower flows and innovation outcomes developed in earlier work (Ettlie, 1980). Using information about 56 food processing firms, he finds that net gain manpower flows stimulate radical process innovation outcomes but tend to be inversely related to other innovation outcomes, i.e. incremental process innovation and the number of new products. But in order to gain from the "new blood", the integration of newcomers has to be managed effectively. Based on the reasoning of Price (1977), who emphasizes both a positive effect of "new blood" 
on innovation and a negative, disruptive force of turnover, Ettlie (1985) stated the hypothesis of a curvilinear relationship between turnover and innovation, but his findings do not give a clear indication of a curvilinear relationship. ${ }^{3}$

Whereas Rao and Drazin (2002) and Ettlie (1985) merely investigated the effects of new personnel and net gains of personnel, respectively, Kaiser et al. (2008) provide the only study which also accounts for the effect of leaving workers. They conducted a firm-level study using a linked-employer employee data set. Their evidence points towards a positive (negative) impact of R\&D workers joining (leaving) a firm on patenting activity. The net effect of labor mobility as measured by the sum of contributions is positive. They furthermore find that the mobility of R\&D workers increases both the patent activity of the donor (the firms which experience the leave of $R \& D$ workers) and recipient (the firms which get new R\&D workers) firms. However, none of the empirical investigations so far studies the effect of employment neutral mobility of R\&D personnel, i.e. churning, on product innovation.

Analyzing the effects of overall employment dynamics at the firm level, Ilmakunnas et al. (2005) find empirical evidence for Jovanovic's (1979) job matching argument. Using ordinary least square regressions they find that churning of employees has a significant positive effect on total factor productivity growth.

To sum up, the empirical literature has yet not used the churning measure to address our research question. Churning is a highly informative measures of employment dynamics and its use allows to disentangle the effect of replacement from net change in R\&D workforce. Furthermore, most studies focus on patent activities. There is no empirical information on how churning effects different types of innovation. Finally, R\&D knowledge was not distinguished by its appropriability regime. With the present empirical analysis, we try to bridge this gap.

Based on the theoretical arguments mentioned above, we will test the following three hypotheses concerning the flows of $R \& D$ workers and innovative outcomes in the empirical analysis:

\footnotetext{
${ }^{3}$ Note that this result is based on a cross-tabulation of the two variables. Ettlie (1985) does not provide a formal test for the hypothesis.
} 
Hypothesis 1: The probability of successfully implementing innovations increases with gains in RED personnel.

Hypothesis 2: Churning of RED personnel is positively related to the probability of successfully implementing innovations up to a specific point. Beyond this point an increase in churning of RED personnel lowers the propensity to innovate (inverse u-shaped relationship).

Besides the conjecture of an increased productivity of $R \& D$ workers due to dissolving poor matches, Hypothesis 2 considerably relies on Cooper's (2001) assumption of a duplicative nature of $\mathrm{R} \& \mathrm{D}$ knowledge. The extent to which R\&D knowledge can be simultaneously used by firms largely depends on how effectively knowledge can be protected and hence appropriated. Positive effects of the churning of R\&D personnel might therefore be (partly) offset if the R\&D knowledge of a firm is non-duplicative.

Hypothesis 3: If REDD knowledge is non-duplicative, the positive impact of churning of RED personnel on successfully implementing innovations is lower.

\section{Empirical analysis}

\subsection{The data}

The empirical analysis employs data from the Mannheim Innovation Panel (MIP). The MIP is an annual innovation survey conducted by the Centre for European Economic Research (ZEW), the Fraunhofer Institute for Systems and Innovation Research (ISI), and the Institute for Applied Social Sciences (infas) on behalf of the German Federal Ministry of Education and Research (BMBF). The target population consists of all firms located in Germany having at least 5 employees in manufacturing, mining, energy, and selected service sectors. The survey is drawn as a stratified random sample and is representative of the corresponding target population. ${ }^{4}$ The survey methodology and definitions of innovation indicators

\footnotetext{
${ }^{4}$ The stratification criteria are firm size ( 8 and 7 size classes according to the number of employees in manufacturing and services, respectively), industry (at the two-digit level according to the NACE Rev.1 classification system with the exception of NACE 22, 24, 64 and 74 where
} 
are strongly related to the recommendations on innovation surveys set out in the Oslo Manual (see OECD and Eurostat (2005); first published in 1992), thereby yielding internationally comparable data on the innovation activities of German firms. The MIP is the German contribution to the Europe-wide harmonized Community Innovation Surveys (CIS) which take place every 4 year and since 2005 every second year.

To test the hypotheses about the impact of churning on firms' innovation performance, we use three survey waves. The 2006 survey provides detailed information about the mobility of R\&D personnel. Our dependent variables, i.e. different measures of innovation performance, are taken from the 2008 survey. Hence, we explain the effect of churning on future innovation performance to reduce potential endogeneity problems. To test hypothesis 3 , we use information about firms' knowledge protection strategies. This information comes from the 2005 survey, as no such information is contained in the 2006 survey. The net samples in 2005, 2006 and 2008 consists of 5,563, 5,187 and 6,624 firms, respectively. Though the surveys are designed as a panel, merging data from three survey waves leads to a considerable reduction in the number of observations since participation is voluntary. For estimation purposes, we further exclude firms with incomplete data for any of the relevant variables (which are discussed in section 3.2), ending up with a sample of 1,576 firms.

\subsection{Variables and method}

This section describes the variables we use in the empirical analysis and the econometric method we apply. A summarizing table of all variables included in the analysis can be found in Table 1 . The respective descriptive statistics are given in Table 2. Most of the explanatory variables are included using lagged values.

a 3-digit level is employed) and region (East and West Germany). A detailed description of the data is given in Peters (2008). 


\section{Measuring innovation}

For measuring innovation performance, we employ four different binary indicators. Similar to Ettlie (1985), we distinguish between product and process innovation in a first step. According to the Oslo Manual, product or process innovators are firms which successfully introduced a new product or process within the previous 3 years, respectively. A product innovation is defined as a new or significantly improved product or service which is brought onto the market by the firm. A process innovation is a new or significantly improved production technology, delivery or distribution method, including methods to provide services, introduced by the firm. Concerning product innovations, we further distinguish between market novelties and product-range novelties in a second step. While market novelties are product innovations that a firm has introduced onto the market prior to any competitor, product-range novelties are product innovations that open up a new product range within the firm, i.e. new products with no predecessors in the innovating firm. Note that market novelties are not necessarily product-range novelties and vice versa. Overall, one third of the firms in our estimation sample have introduced at least one product innovation between 2005 and 2007. One fourth has introduced process innovations within that time. A fraction of 15 percent introduced products which were new to the market and 20 percent of all firms in the estimation sample have introduced product-range novelties.

\section{Measuring flows of R\&D workers}

Employment fluctuations within a firm can be measured using various indicators. Common measures are the number of hirings or the number of separations over total employment (hiring and separation rates). Often the turnover rate (sum of hirings and separations over total employment) is used when analyzing worker flows. More recent studies have introduced a concept called "churning" or "excess worker reallocation", which describes the amount of workers replaced by new ones (e.g. Lane et al., 1996; Burgess et al., 2001; Ilmakunnas et al., 2005). If 3 employees leave a firm during a specific period and the firm hires 5 new employees during that period, a firm has a churning of 3 workers and a net gain of 2 
employees. If another firm records 5 separation during that time and hires 3 new employees, this firm has also a churning of 3 workers, but a net loss of 2 employees. Both firms have the same amount of churning, but they differ with respect to their employment growth. Because of this property, the churning measure is often interpreted as "excess worker reallocation". Churning measures the amount of employment fluctuations which exceeds the amount of hirings or separations necessary for a change in total employment. Therefore, the measure abstracts from changes in total employment. We calculate the amount of churning of R\&D workers in firm $i$ as follows:

$$
C_{i}=\frac{1}{2}\left(H_{i}+S_{i}-\left|H_{i}-S_{i}\right|\right)
$$

where $H_{i}$ is the number of newly hired R\&D workers between 2003 and 2005 and $S_{i}$ denotes the number of R\&D workers who left the firm between 2003 and 2005. Though our hypotheses state that labor mobility affects innovation, we cannot rule out inverse causality, i.e. that innovation is initiated which requires and attracts new personnel (Ettlie, 1985). Due to data constraints, we cannot test for causality. To alleviate potential endogeneity problems of our main variable, we include a lagged measure of churning. The distribution of churning is highly skewed with an average churning in our estimation sample of $3.1 \mathrm{R} \& \mathrm{D}$ workers. Hence, we estimated the model using the churning rate $C R_{i}=\frac{C_{i}}{N_{i}}$, with $N_{i}$ measuring the average number of $R \& D$ workers in 2005 . On average 2.7 percent of the R\&D personnel was successfully replaced.

In order to test hypothesis 2 , we include the churning rate as well as a squared term of the churning rate in our regressions since the relationship between churning and innovation might be inverse u-shaped as supposed by Ettlie (1985).

We further calculated the growth rate of RED employment to account for (positive or negative) net gains in $\mathrm{R} \& \mathrm{D}$ personnel. On average, R\&D employment has increased by 2.4 percent. If hypothesis 1 is true, we should observe a positive relationship between the growth of $R \& D$ employment and the probability of introducing an innovation. 
Table 1: Description of variables

\begin{tabular}{|c|c|c|}
\hline Variable & Description & Source \\
\hline Product innovation & $\begin{array}{l}\text { New or significantly improved products } \\
\text { and/or services with respect to technological } \\
\text { characteristics or intended uses, which are } \\
\text { brought onto the market by the firm in } \\
2005-2007\end{array}$ & MIP 2008 \\
\hline Process innovation & $\begin{array}{l}\text { New or significantly improved production, } \\
\text { delivery or distribution methods, including } \\
\text { methods to provide services, introduced by } \\
\text { the firm in } 2005-2007\end{array}$ & MIP 2008 \\
\hline Market novelties & $\begin{array}{l}\text { Product innovations that a firm has } \\
\text { introduced onto the market prior to any } \\
\text { competitor in 2005-2007 }\end{array}$ & MIP 2008 \\
\hline Product-range nov. & $\begin{array}{l}\text { Product innovation in } 2005-2007 \text { that have } \\
\text { no predecessors in the innovating firms }\end{array}$ & MIP 2008 \\
\hline Churning rate $(C R)$ & $\frac{\text { Churning 2003-2005 }}{\text { R\&D personnel (average in 2005) }} \times 100$ & MIP 2006 \\
\hline Churning $(C)$ & Churning between 2003 and 2005 (level) & MIP 2006 \\
\hline Non-duplicative knowledge & $\begin{array}{l}\text { Indicator for non-duplicative knowledge } \\
\text { within the firm: Firm declares the use of } \\
\text { secrecy to be highly important for knowledge } \\
\text { protection. }\end{array}$ & MIP 2005 \\
\hline R\&D Personnel (growth) & Growth of R\&D personnel from 2003 to 2005 & MIP 2006 \\
\hline R\&D personnel (level) & Average number of R\&D workers (2005) & MIP 2006 \\
\hline Log(employees) & $\begin{array}{l}\text { Logarithm of the number of firm's non R\&D } \\
\text { employees (average in 2005) }\end{array}$ & MIP 2006 \\
\hline Share of high-skilled empl. & $\begin{array}{l}\text { Share of employees with a university or } \\
\text { college degree in } 2005\end{array}$ & MIP 2006 \\
\hline Export intensity & 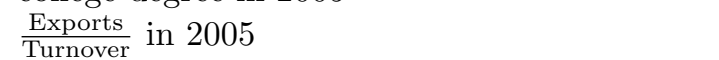 & MIP 2006 \\
\hline Log(labor productivity) & $\begin{array}{l}\text { Logarithm of firm's labor productivity } \\
\left(\frac{\text { Turnover (in thousand EUR) }}{\# \text { employees }}\right) \text { in } 2005\end{array}$ & MIP 2006 \\
\hline Log(age) & Logarithm of firm's age in 2007 & Creditreform \\
\hline Eastern Germany & Firm is located in eastern Germany & Creditreform \\
\hline Limited Liability & $\begin{array}{l}\text { Legal form results in limited liability of the } \\
\text { firm's owners }\end{array}$ & Creditreform \\
\hline Other manufacturing & Other manufacturing (OECD definition) & MIP 2008 \\
\hline Low-tech manuf. & $\begin{array}{l}\text { Low-technology manufacturing (OECD } \\
\text { definition) }\end{array}$ & MIP 2008 \\
\hline Medium-tech manuf. & $\begin{array}{l}\text { Medium-technology manufacturing (OECD } \\
\text { definition) }\end{array}$ & MIP 2008 \\
\hline High-tech manuf. & $\begin{array}{l}\text { High-technology manufacturing (OECD } \\
\text { definition) }\end{array}$ & MIP 2008 \\
\hline Knowledge-int. services & $\begin{array}{l}\text { Knowledge-intensive services (OECD } \\
\text { definition) }\end{array}$ & MIP 2008 \\
\hline Low knowl.-int. services & $\begin{array}{l}\text { Low knowledge-intensive services (OECD } \\
\text { definition) }\end{array}$ & MIP 2008 \\
\hline
\end{tabular}


Table 2: Descriptive statistics

\begin{tabular}{|c|c|c|c|c|}
\hline Variable & Mean & Std. Dev. & Min & Max \\
\hline \multicolumn{5}{|l|}{ Dependent variables } \\
\hline Product innovation & 0.337 & 0.473 & 0 & 1 \\
\hline Process innovation & 0.266 & 0.442 & 0 & 1 \\
\hline Market novelties & 0.152 & 0.359 & 0 & 1 \\
\hline Product-range nov. & 0.198 & 0.399 & 0 & 1 \\
\hline \multicolumn{5}{|l|}{ Independent variables } \\
\hline Churning rate $(C R)^{a)}$ & 2.659 & 10.500 & 0 & 150 \\
\hline Churning level $(C)$ & 3.099 & 37.833 & 0 & 1098 \\
\hline Non-duplicative knowledge & 0.177 & 0.382 & 0 & 1 \\
\hline R\&D Personnel (growth) & 2.391 & 16.267 & -100 & 150 \\
\hline R\&D personnel (level) & 20.542 & 176.792 & 0 & 3753.75 \\
\hline Log(employees) & 3.729 & 1.930 & -13.816 & 11.345 \\
\hline Share of high-skilled empl. & 19.584 & 23.755 & 0 & 100 \\
\hline Export intensity & 12.624 & 22.359 & 0 & 100 \\
\hline Log(labor productivity) & -1.490 & 0.900 & -4.674 & 3.069 \\
\hline Log(age) & 2.810 & 0.744 & 0 & 5.541 \\
\hline Eastern Germany & 0.380 & 0.486 & 0 & 1 \\
\hline Limited Liability & 0.841 & 0.366 & 0 & 1 \\
\hline \multicolumn{5}{|l|}{ Industry ${ }^{1}$} \\
\hline Other manufacturing & 0.077 & 0.266 & 0 & 1 \\
\hline Low-tech manuf. & 0.153 & 0.360 & 0 & 1 \\
\hline Medium-tech manuf. & 0.266 & 0.442 & 0 & 1 \\
\hline High-tech manuf. & 0.063 & 0.243 & 0 & 1 \\
\hline Knowledge-int. services & 0.289 & 0.453 & 0 & 1 \\
\hline Low knowl.-int. services & 0.152 & 0.359 & 0 & 1 \\
\hline
\end{tabular}

Note: a) $C R$ is not bounded at 100. For example, if a firm has 3 R\&D workers initially, 2 hirings and 4 separations within the period 2003-2005, then the churning rate amounts to $\frac{2}{1} \times 100=200$.

Source: MIP 2005, 2006, 2008, authors' calculations. 
Hypothesis 3 is tested using information about the importance of different knowledge protection measures. The method most often used to protect knowledge is secrecy. If a firm stated that it uses secrecy as a measure of knowledge protection and classifies the use of secrecy as highly important, we question the duplicative nature of this firm's R\&D knowledge. Assuming a duplicative nature of a firm's R\&D knowledge implies that a firm can use the knowledge an $R \& D$ worker has produced even if the respective worker has left the firm. If a firm assigns secrecy as highly important, a firm fears to loose at least parts of this knowledge. In this case, the R\&D knowledge of the firm is non-duplicative. Overall, 17.7 percent of the firms in our sample can be characterized by a nonduplicative nature of their $R \& D$ knowledge. We included the dummy variable non-duplicative knowledge in the regressions and investigate if the supposed positive effects of churning on innovation cancel out by including an interaction effect of that dummy and the churning measure.

\section{Control variables}

We control for a set of additional firm characteristics which have been shown to be related to innovation performance of firms in previous studies (Acs and $\mathrm{Au}$ dretsch, 1988; Bhattacharya and Bloch, 2004). Specifically, we control for size effects as measured by the total number of non-R\&D workers (log(employees)) and innovation input proxied by the level of $R \& D$ personnel. We further account for innovative capabilities by including the share of high-skilled employees. The effect of international activities on innovation (Almeida and Fernandes, 2006) is captured by incorporating the export intensity. Finally, differences in overall labor productivity (log(labor productivity)), firm age (Huergo and Jaumandreu, 2004), regional location (Eastern Germany), and the legal form through liability differences (limited liability) may affect innovation (Ayygari et al., 2007). With respect to industry differences, we distinguish six industries concerning their global technological intensity as proposed by the OECD. The category other manufacturing serves as reference category in the estimations. 


\section{Estimation strategy}

Since we suppose that the decision to introduce product and process innovations is not independently determined, we apply bivariate probit estimations. In a second step, we identify the effect of churning on different types of product innovations, namely market novelties and product-range novelties. The bivariate probit is a natural extension of the probit model which, similar to seemingly unrelated regression models, allows for two equations with correlated disturbances $\varepsilon_{1}$ and $\varepsilon_{2}$ (Greene, 2003). We estimate two sets of bivariate probit regression models described by

$$
\begin{aligned}
y_{1}^{*}=x^{\prime} \beta_{1}+\varepsilon_{1}, \quad y_{1} & =1 \text { if } y_{1}^{*}>0, y_{1}=0 \text { otherwise } \\
y_{2}^{*}=x^{\prime} \beta_{2}+\varepsilon_{2}, \quad y_{2} & =1 \text { if } y_{2}^{*}>0, y_{2}=0 \text { otherwise } \\
E\left(\varepsilon_{1} \mid x\right) & =E\left(\varepsilon_{2} \mid x\right)=0 \\
\operatorname{Var}\left(\varepsilon_{1} \mid x\right) & =\operatorname{Var}\left(\varepsilon_{2} \mid x\right)=1 \\
\operatorname{Cov}\left(\varepsilon_{1}, \varepsilon_{1} \mid x\right) & =\rho .
\end{aligned}
$$

The dependent variables are denoted by $y_{1}$ and $y_{2}$ with their unobserved latent variables $y_{1}^{*}$ and $y_{2}^{*}, x$ is the vector of independent variables, and $\beta$ is the vector of coefficients to be estimated.

\subsection{Estimation results}

Results of the bivariate probit regressions are presented in Table 3 for product and process innovations and in Table 4 for market novelties and product-range novelties. First, the model was estimated without the interaction of the dummy variable non-duplicative knowledge (Models 1) and afterwards firms were distinguished by the nature of their R\&D knowledge (Models 2).

In all models we observe a significant positive influence of the growth rate of R\&D personnel on the probability to innovate. This confirms hypothesis 1 . 


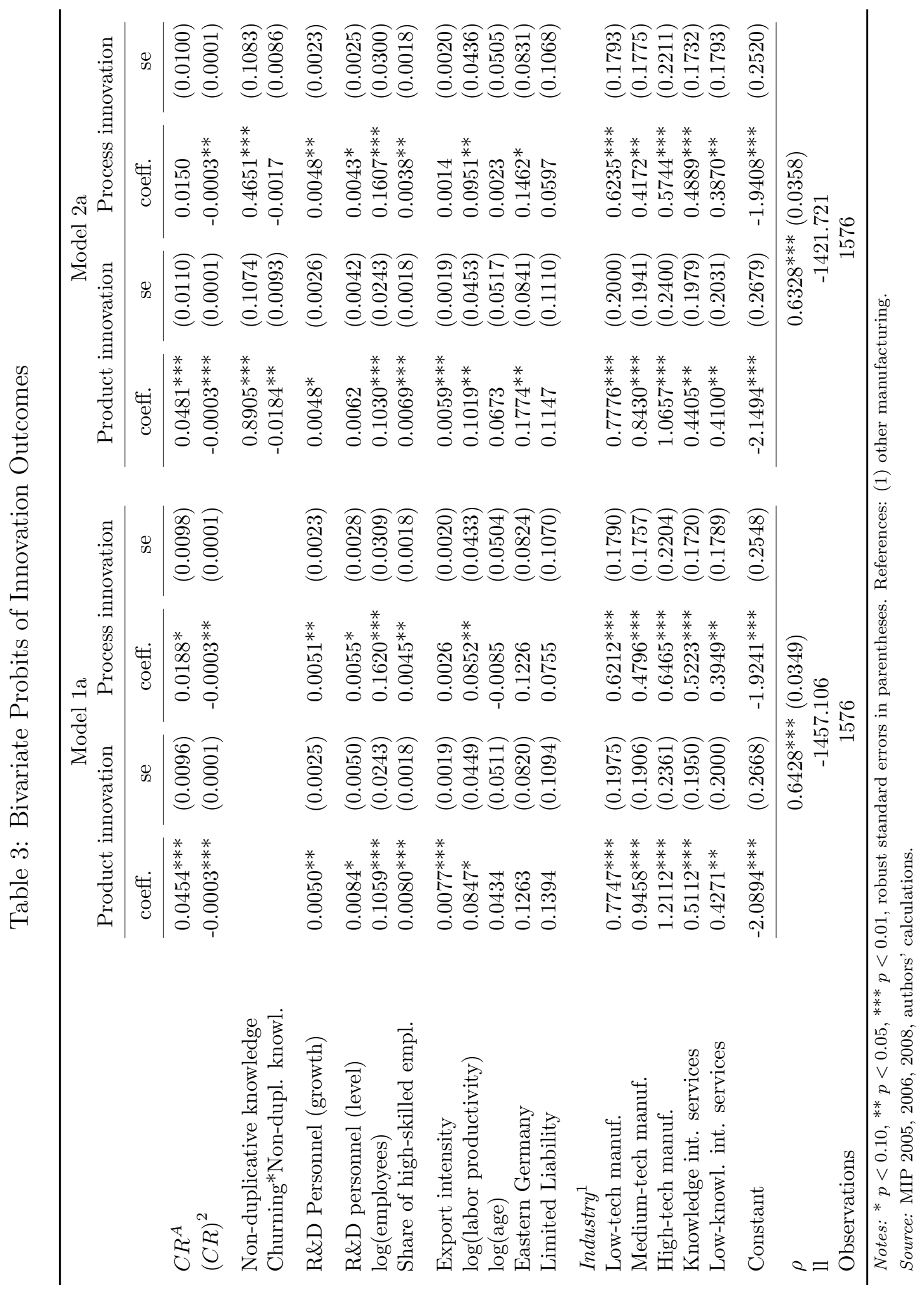




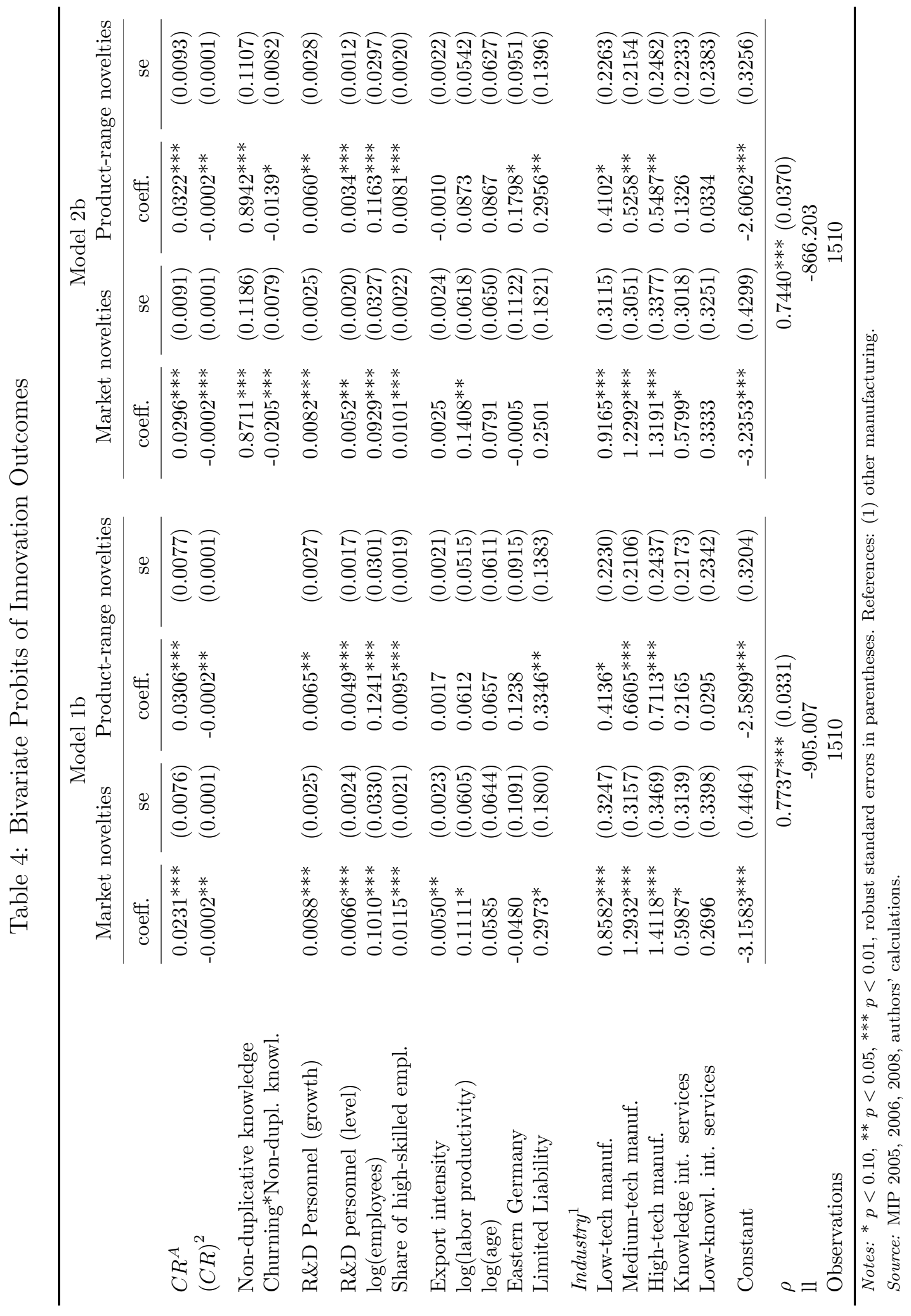


The results further show that the churning rate $(C R)$ has a significant influence on both product and process innovations. Since the coefficient estimate of the square term is significantly negative, the relationship between churning of $\mathrm{R} \& \mathrm{D}$ personnel and innovation outcomes is to found to be inverse u-shaped. This finding is in favor of hypothesis 2 . The same is true for market novelties and product-range novelties.

For all types of innovations except of process innovations, the effect is robust to introducing the variables which distinguish firms by the nature of their R\&D knowledge. Firms which declare the use of secrecy to be highly important for knowledge protection have a higher probability to introduce product innovations and process innovations. This effect is not surprising since by construction the dummy non-duplicative nature may also indicate that the firm has accumulated a large stock of knowledge which has to be protected and which serves as base for further innovation activities in the future.

Distinguished by the nature of their knowledge using the indicator variable non-duplicative knowledge, churning exhibits a different influence on the probability to innovate. The coefficients on the churning rate, the square of the churning rate, the non-duplicative knowledge dummy, and the interaction effect are jointly significant at the 1 percent level in all models.

Interestingly, the effect of churning on the probability to introduce product innovations peaks at a churning rate of 65 percent whereas the peak for process innovations lies at 30 percent (see Figure 1a and Figure 1c). That is, the optimal amount of churning among R\&D workers is larger for product innovations than for process innovations. This result can be explained by the fact that much more firm-specific knowledge is needed for significantly improving production processes within a firm than for developing new products. Hence, the disruptive effect of churning starts earlier for process innovation. For firms with non-duplicative R\&D knowledge, the probability to introduce product innovations peaks at a churning rate of 45 percent. If $R \& D$ knowledge is duplicative, the effect peaks at a churning rate of 70 percent (see Figure 1b). Firms with non-duplicative R\&D knowledge have a higher probability of introducing product innovations than firms with duplicative R\&D knowledge as long as the churning rate is below 50 percent. 
This result is in line with hypothesis 3 since it indicates that the positive effect of churning is partly offset for firms where the knowledge is non-duplicative.

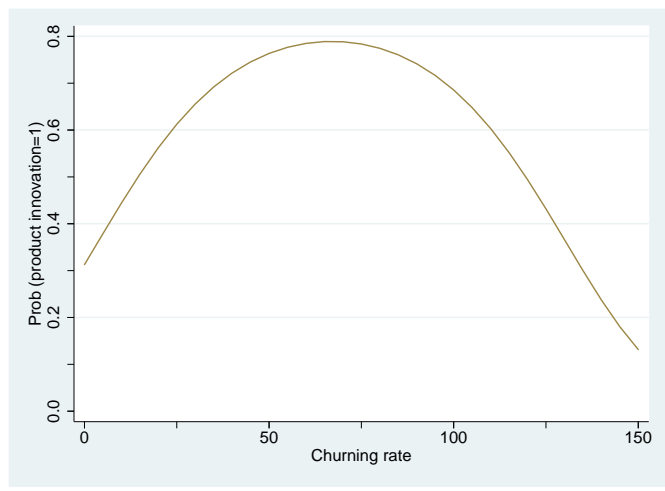

(a) Product innov. - model 1a

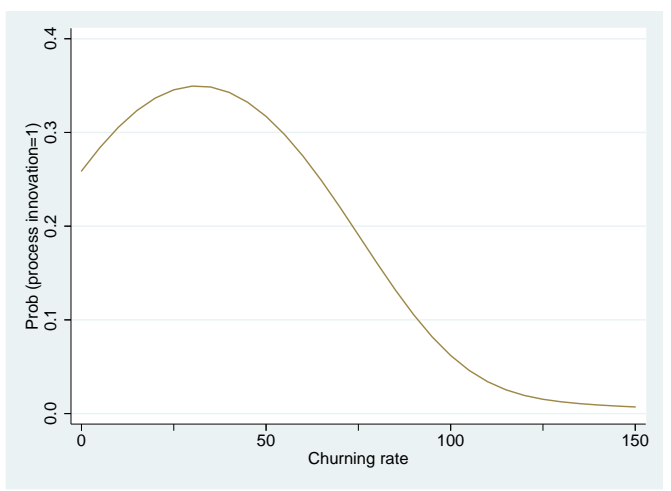

(c) Process innov. - model 1a

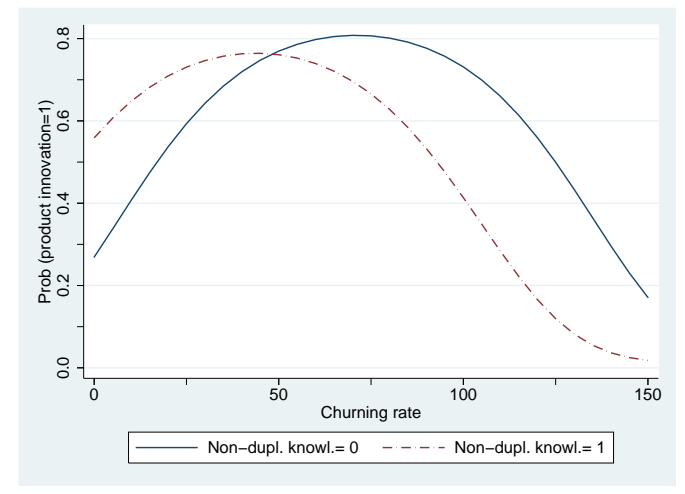

(b) Product innov. - model 2a

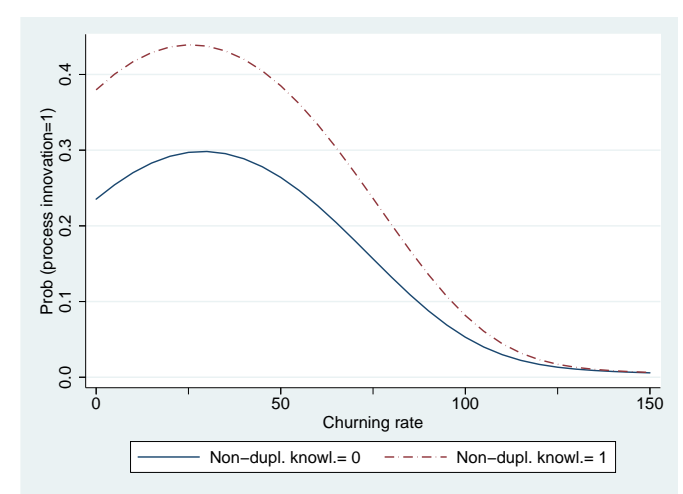

(d) Process innov. - model 2a

Figure 1: Churning and the probability of product and process innovations

Note: Average predictions. Model 1a does not account for the interaction of non-duplicative knowledge and churning (left side) while model 2a does (right side).

Source: MIP 2005, 2006, 2008, author's calculations.

Since the interaction effect for process innovations is small and far beyond significance, the effect of churning on the probability to introduce process innovations peaks regardless the nature of knowledge at around 25 percent (see Figure 1d). Thus, hypothesis 3 cannot be confirmed for process innovation.

Concerning market novelties, we estimate a point of inflexion of 65 percent, while the probability to introduce product-range novelties peaks at a churning rate of 85 percent (Figure 2a and Figure 2c). Compared to findings of Ettlie (1985) this result may be surprising at first glance. It says that the reallocation 
of $\mathrm{R} \& \mathrm{D}$ workers is more likely to stimulate the introduction of new products which were outside the existing product-range than of market novelties. But note that firms can launch market novelties within their existing product range where they already have shown expertise. Introducing new products for which there are no predecessors in the firm, however, obviously requires more external knowledge which can be gained through labor mobility.

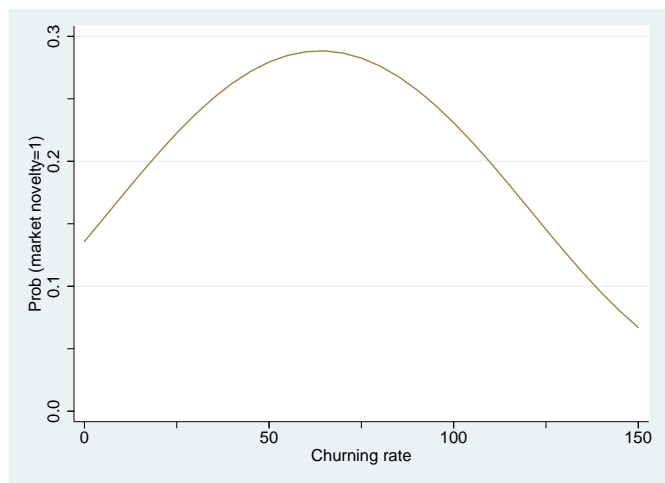

(a) Market nov. - model $1 \mathrm{~b}$

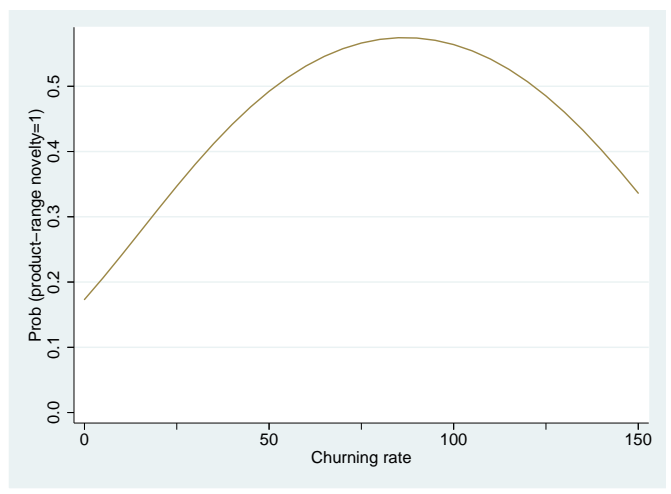

(c) Product-range nov. - model 1b

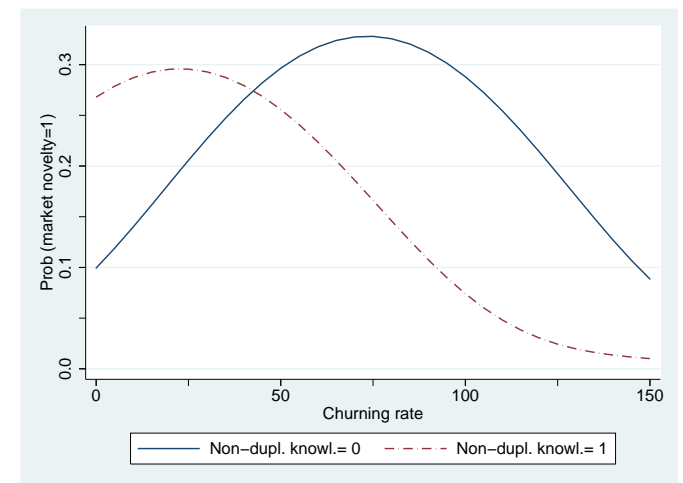

(b) Market nov. - model $2 \mathrm{~b}$

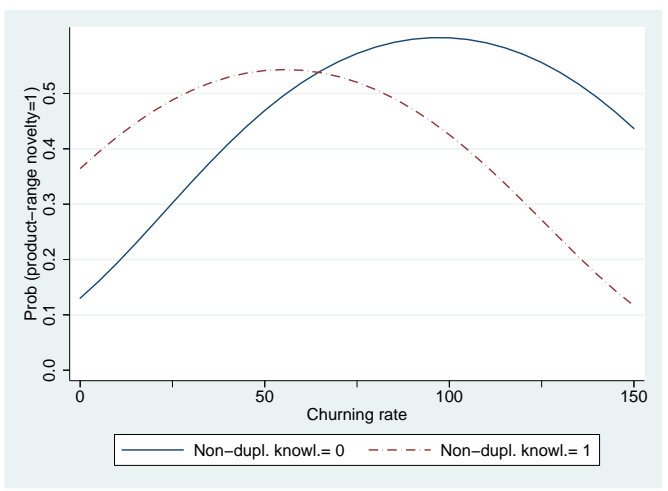

(d) Product-range nov. - model 2b

Figure 2: Churning and the probability of market and product-range novelties

Note: Average predictions. Model $1 \mathrm{~b}$ does not account for the interaction of non-duplicative knowledge and churning (left side) while model $2 \mathrm{~b}$ does (right side).

Source: MIP 2005, 2006, 2008, author's calculations.

Figure $2 \mathrm{~b}$ and Figure $2 \mathrm{~d}$ display the effect of churning on the probability to introduce market novelties and product-range novelties distinguished by the nature of $R \& D$ knowledge. The effect on market novelties (product-range novelties) peaks at 25 percent ( 55 percent) if $R \& D$ knowledge is non-duplicative and at 75 
percent (95 percent) if $\mathrm{R} \& \mathrm{D}$ knowledge can be assumed to be duplicative. The probability to introduce market novelties (product-range novelties) is higher for firms having accumulated non-duplicative knowledge as long as the churning rate is below 45 percent (65 percent).

The control variables show the expected signs. Size (log(employees)) is found to exert a positive effect on innovation. Also, innovation inputs are found to be positively related to innovation outcomes. But the coefficient for the number of a company's R\&D workers is not significantly different from zero for product innovations in general. The share of high-skilled employees positively influences the probability to innovate in all models and all equations. Exporting is only found to be positively correlated to product innovation. Overall labor productivity turns out to be positively related to innovation except for product-range novelties. The industry dummies are jointly significant in all models and all equations.

\section{Conclusions}

This paper has investigated the consequences of R\&D worker mobility on innovation performance at the firm level. We contribute to the literature of inventor mobility and innovation success by conducting an analysis at the firm level which first adopts a measure of labor mobility developed in labor economics: the churning of R\&D personnel.

In developing our hypothesis, we refer to the theories of Jovanovic (1979) and Cooper (2001). According to these theories, labor mobility increases the employer-employee matching quality within the R\&D department (Jovanovic, 1979). Furthermore, labor mobility results in net inflows of $R \& D$ knowledge (Cooper, 2001). However, if churning of R\&D personnel is very high, costs may exceed the benefits and the relationship between churning and innovation is more likely to be inverse u-shaped. In our empirical analysis, we first distinguished between product and process innovation. In a second step, we further distinguished between product-range novelties and market novelties. We employed bivariate probit estimations. Our hypothesis of an inversed u-shaped relationship between churning and innovation can be confirmed for various kinds of innovation output 
measures. Interestingly, the point beyond which an increase in churning of $R \& D$ personnel lowers the propensity to innovate differs between the different types of innovation. However, the point beyond which an increase in churning of R\&D personnel lowers the propensity to innovate is very high except for process innovations. We conclude from these findings that process innovations require much more firm-specific knowledge than product innovations. This applies particularly to firms with duplicative R\&D knowledge. Mostly, the returns to churning are found to be positive even when more than half of the researchers are replaced. Especially product-range innovations are found to largely benefit from inflows of external knowledge by means of R\&D worker mobility. If a firm's R\&D knowledge is non-duplicative, as measured by the importance of secrecy as a knowledge protection mechanism, positive effects of churning on innovation performance are found to be partly offset in case of product innovations. The point when costs of churning exceed the benefits is reached faster if the R\&D knowledge is not duplicative than if the R\&D knowledge is duplicative.

The results of our study have several implications for innovation management. First, innovation performance may be impeded by statical personnel structure within $R \& D$ departments. More dynamics are required in order to get access to new knowledge and to dissolve poor employee matches. Therefore, a firm should maintain a moderate level of churning among its R\&D workers. However, a firm should take care that its churning does not exceed a certain threshold. Accordingly, labor agreements should be sufficient flexible on both sides. The period of notice should be reasonable in order not to hamper R\&D workers' mobility and to hinder knowledge flows. Furthermore, the use of non-compete clauses is disadvantageous for both employer and employee if a firm's R\&D knowledge is duplicative. Firms might even profit from delegating an R\&D worker to a competitor for a specific project or a certain period of time. Moreover, firms might even think about retracting $R \& D$ workers who have left the firm a while ago in order to benefit from the knowledge this worker has gained working for the other firm.

One the other hand, policy makers should be aware that an increase in labor market flexibility (e.g. dismissal protection) does not only affect labor market outcomes but may also be an additional route to foster innovation by encourag- 
ing improvements in the job-match qualities and by facilitating the diffusion of knowledge.

\section{References}

Acs, Z. And D. Audretsch (1988): "Innovation in Large and Small Firms: An Empirical Analysis," American Economic Review, 78, 678-690.

Almeida, P. And B. Kogut (1999): "Localization of Knowledge and the Mobility of Engineers in Regional Networks," Management Science, 45, 905-916.

Almeida, R. And A. Fernandes (2006): "Openness and Technological Innovation in Developing Countries: Evidence from Firm-level Data," World Bank Policy Research Working Paper No. 3985.

Aoshima, Y. (2008): "Mobility of R\&D Workers and Technological Performance," Japan Labor Review, 5, 33-60.

Arora, A. And A. Gambardella (1994): "Evaluating Technological Information and Utilizing it," Journal of Economic Behaviour and Organization, 24, 91-114.

Ayygari, M., A. Demirguc-Kunt, And V. Maksimovic (2007): "Firm Innovation in Emerging Markets," World Bank Policy Research Working Paper No. 4157.

Baker, W. (1994): Networking Smart: How to Build Relationships for Personal and Organizational Success, New York: McGraw-Hill.

BARney, J. B. (1991): "Firm Resources and Sustained Competitive Advantage," Journal of Management, 17, 99-120.

Bhattacharya, M. And H. Bloch (2004): "Determinants of Innovation," Small Business Economics, 22, 155-162.

Burgess, S., J. Lane, And D. Stevens (2000a): "Job Flows, Worker Flows, and Churning," Journal of Labor Economics, 18, 473-502. 
(2000b): "The Reallocation of Labour and the Lifecycle of Firms," Oxford Bulletin of Economics and Statistics, 62, 885-907.

(2001): "Churning dynamics: An Analysis of Hires and Separations at the Employer Level," Labour Economics, 8, 1-14.

Cassiman, B. And R. Veugelers (2006): "In Search of Complementarity in Innovation Strategy: Internal R\&D and External Knowledge Acquisition," Management Science, 52, 68-82.

— (2007): “Are External Technology Sourcing Strategies Substitues or Complements? The Case of Embodied Versus Disembodied Technology Acquisition," IESE working paper 672, Barcelona.

Cooper, D. (2001): "Innovation and Reciprocal Externalities: Information Transmission via Job Mobility," Journal of Economic Behavior and Organizations, 45, 403-425.

Crépon, B., E. Duguet, And J. Mairesse (1998): "Research, Innovation and Productivity: An Econometric Analysis at the Firm Level," Economics of Innovation and New Technology, 7, 115-158.

Ettlie, J. (1980): "Manpower Flows and the Innovation Process," Management Science, 26, 1086-1095.

— (1985): "The Impact of Interorganizational Manpower Flows on the Innovation Process," Management Science, 31, 1055-1071.

Fallick, B., C. Fleischman, And J. Rebitzer (2006): "Job-Hopping in Silicon Valley: Some Evidence Concerning the Microfoundations of a HighTechnology Cluster," Review of Economics and Statistics, 88, 472-481.

Greene, W. (2003): Econometric Analysis, Upper Saddle River, New Jersey: Prentice Hall, 5th ed.

Hagedoonn, J. (2002): "Inter-Firm R\&D Partnerships," Research Policy, 31, 477-492. 
HoisL, K. (2007): "Tracing Mobile Inventors - The Causality Between Inventor Mobility and Inventor Productivity," Research Policy, 36, 619-636.

Huergo, E. And J. Jaumandreu (2004): "How Does Probability of Innovation Change with Firm Age?" Small Business Economics, 22, 193-207.

Ilmakunnas, P., M. Maliranta, And J. VainiomÄKi (2005): "Worker Turnover and Productivity Growth," Applied Economics Letters, 12, 395-398.

Jovanovic, B. (1979): "Job Matching and the Theory of Turnover," Journal of Political Economy, 87, 972-990.

Kaiser, U., H. Konstedt, And T. Rønde (2008): "Labor Mobility and Patenting Activity," CAM Working Paper No. 2008-07, Copenhagen.

Kim, J. And G. MARSChKe (2005): "Labor mobility of scientists, technological diffusion, and the firm's patenting decision," RAND Journal of Economics, 36, $298-317$.

Lane, J., A. IsaAc, And D. Stevens (1996): "Firm Heterogeneity and Worker Turnover," Review of Industrial Organization, 11, 275-291.

Liu, P.-W. (1986): "Human Capital, Job Matching and Earnings Growth Between Jobs: An Empirical Analysis," Applied Economics, 18, 1135-1147.

Love, J. H. And S. Roper (2001): "Location and Network Effects on Innovation Sucess: Evidence for UK, Germany and Irish Manufacturing Plants," Research Policy, 30, 643-661.

OECD And Eurostat (2005): Oslo Manual: Guidelines for Collecting and Interpreting Innovation Data, Paris: OECD, third edition ed.

Pakes, A. And Z. Griliches (1984): "Patents and R\&D at the Firm Level: A First Look," in RED, Patents, and Productivity, ed. by Z. Griliches, Chicago, $55-71$.

Pakes, A. And S. Nitzan (1983): "Optimum Contracts for Research Personnel, Research Employment, and the Establishment of "Rival" Enterprises," Journal of Labor Economics, 1, 345-365. 
Price, J. (1977): The Study of Turnover, Ames, Iowa: Iowa State University Press.

RaO, H. And R. Drazin (2002): "Overcoming Resource Constraints on Product Innovation by Recruiting Talentfrom Rivals: A Study of the Mutual Fund Industry, 1986-94," Academy of Management Journal, 45, 491-507.

Saxenian, A. (1994): Regional Advantage: Culture and Competition in Silicon Valley and Route128, Cambridge, Massachusetts: Harvard University Press.

Teece, D. (1986): "Profiting from Technological Innovation. Implications for Integration, Collaboration,Licensing and Public Policy," Research Policy, 15, $285-305$.

(1992): "Competition, Cooperation, and Innovation: Organizational Arrangements for Regimes of Rapid Technological Progress," Journal of Economic Behaviour and Organization, 18, 1-25.

Topel, R. And M. WARd (1992): "Job Mobility and the Careers of Young Men," Quarterly Journal of Economics, 107, 439-479. 